\title{
Using Seasonal Climate Variability Forecasts: Risk Management for Tomato Production in South Florida ${ }^{1}$
}

\author{
Norman Breuer, Phyllis Gilreath, Gene McAvoy, David Letson, and Clyde Fraisse ${ }^{2}$
}

This paper is divided into three main sections. The first part briefly describes the difference between weather and climate. The second section suggests some management options available to tomato growers with regards to seasonal climate forecasts. The third part discusses economic and risk management implications of seasonal climate variability for tomato producers and extensionists looking at a broader context in South Florida.

\section{A. Part One: Climate and Weather}

\section{Seasonal Climate Variability and Prediction}

Recent advances in atmospheric research have made it possible to predict climate, with a relatively high level of certainty. Knowledge of climatic conditions allows us to develop a seasonal management strategy for tomato production in South Florida. Areas of application include planting date, variety, acreage, insurance options, and perhaps others. This publication provides potential strategies for managing tomato production in South Florida in light of the fact that climate conditions can be better predicted based on the El Niño Southern Oscillation (ENSO) phenomenon.

\section{Climate (longer term planning) vs. Weather (short term planning)}

Some tomato management options may be changeable according to improved climate predictions. The emphasis here is on the six-month to one-year planning horizon. Climate refers to seasonal climate variability. Management options described here are not pertinent to the daily or weekly operational planning as may be influenced by weather forecasts.

Typically, we are speaking of weather when our time frame is no more than the upcoming week. Climate refers to a wet, cool summer or a hot, dry winter. Recently, the ability for meteorologists to predict the climate of upcoming seasons has vastly improved. Oscillations of the Pacific Ocean's sea surface temperature above and below normal are a major contributing factor in determining seasonal climate in the Southeastern United States. Generally,

1. This document is Circular 1450, one of a series of the Agricultural and Biological Engineering Department, Florida Cooperative Extension Service, Institute of Food and Sciences, University of Florida. First published June 2004. Please visit the Web site at http://edis.ifas.ufl.edu.

2. Norman Breuer, PhD, Southeast Climate Consortium; Phyllis Gilreath, Extension Agent IV, Manatee County, University of Florida Cooperative Extension; Gene McAvoy, Extension Agent III, Hendry County, University of Florida Cooperative Extension; David Letson, Associate Professor of Marine Affairs, Rosenstiel School of Marine and Atmospheric Science, University of Miami; and Clyde Fraisse, Assistant Extension Scientist, Agricultural and Biological Engineering Department, University of Florida.

The Institute of Food and Agricultural Sciences (IFAS) is an Equal Employment Opportunity - Affirmative Action Employer authorized to provide research, educational information and other services only to individuals and institutions that function without regard to race, creed, color, religion, age, disability, sex, sexual orientation, marital status, national origin, political opinions or affiliations. For information on obtaining other extension publications, contact your county Cooperative Extension Service office. Florida Cooperative Extension Service / Institute of Food and Agricultural Sciences / University of Florida / Larry R. Arrington, Interim Dean 
the effect is stronger further south than north, and stronger in winter-spring than in summer-fall.

An extreme case of this phenomenon was the 1982-1983 El Niño. The world's climate was affected by a strong temperature increase in the Pacific Ocean. This brought high rainfall along the Gulf of Mexico Coast, while other parts of the country experienced a warm and dry winter. It was observed that ocean temperatures affect climate because they shift the position of the jet stream across the continent. The jet stream consists of relatively strong winds concentrated within a narrow stream in the atmosphere. The term generally refers to a quasi-horizontal jet stream of maximum winds embedded in the mid-altitude westerlies, and concentrated in the high troposphere. This in turn influences fronts and other weather systems for several months. Because the jet stream is strongest in winter months, climate shifts are more pronounced in the cold season. Research into these phenomena led to the ability to predict climate using sea surface temperature. While the El Niño of 1982-83 or of 1997-98 were memorable due to their intensity, a predicted El Niño or La Niña event does not necessarily refer to these type of extremes.

El Niño typically brings more rainfall and cooler temperatures to Florida in the Fall and Winter, while La Niña brings a warmer and much drier than normal Fall and Winter. Table 1 summarizes the effects of El Niño and La Niña on Florida's climate. El Niño/La Niña climate effects start in October and peak during January through March. They are weaker during April through June. Also El Niño/La Niña has little effect during the months from July through September (O'Brien et al., 1999).

\section{B. Part Two: Seasonal Climate Variability-Related Management Options in Tomato Production}

\section{Planting Date}

Researchers at the University of Florida ran crop models to determine the effects of planting date on yield under different El Niño and La Niña phases. Results showed that planting date is an important factor relating ENSO-related climate anomalies and yield. ENSO effects on tomato yields vary with transplant date. Marketable yields differed significantly between El Niño and neutral years for transplant dates from November 9th to the 23rd (Messina et al., 2001). El Niño or La Niña impacts are even greater in winter plantings, as climate effects tend to be strongest in these months.

The Southeast Climate Consortium is developing a Web-based decision support system that will help growers and extensionists evaluate planting date impacts on yield for different climate scenarios. Tomato producers can factor the information into their decision-making process. The probabilities should not convey the idea of not planting on certain dates. Rather, the information can suggest more concentrated transplanting on dates where higher yield probabilities are shown. The information is available from the Agricultural and Biological Engineering Department, UF, local Extension offices, and on a Web site currently under construction: www.agclimate.org (Fraisse.C., Uryasev, O., and Jones, J.W.)

Figure 1 shows the relationship between planting date and tomato yield under different ENSO phases.

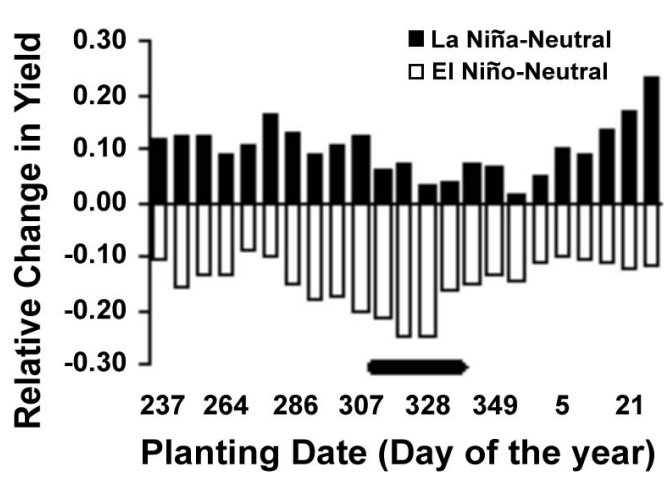

Figure 1. Relationship between planting date and tomato yield under different ENSO phases. Source: Messina et. al 2001.

\section{Tomato Varieties and ENSO}

We refer here specifically to large fruit varieties for south and southwest Florida. Many varieties exist on the market and more specific information on individual varieties is available from county extension specialists and from private seed companies. Varieties used here are prevalent in the 
state and are included as illustrative of how some aspects of management can be tailored according to different ENSO forecasts.

In dry warm weather, viruses caused by thrips (Tomato Spotted Wilt [TSW]) and white fly (Tomato Yellow Leaf Curl [TYLCV]) are problems. Fusarium races 1,2, and 3, and soil borne fungal problems are exacerbated in wet weather. In cool wet winters, "gray wall," blotching, and other fruit quality problems are common. Cloudy, cool, rainy or foggy weather, and/or excess nitrogen conditions greatly increase fruit damage. The variety to plant is typically decided upon several months in advance in order to secure seed and arrange for transplant production. A grower could decide for example to plant more hot-set varieties or more $47 \mathrm{~s}$ and $91 \mathrm{~s}$, which are resistant to Fusarium wilt races 1, 2, and 3. Growers decide the variety according to their customer's preferences and growing conditions for the season, as well as seed availability. When different seasonal climate is expected but surrounded by much uncertainty, varieties that concentrate fruit set on first pick might be preferred. Table 2 may help as a simple guide as to how some varieties behave under seasonal climate variability.

\section{Production Factors Influenced by Climate}

\section{Pests and Diseases}

Principal problems for tomatoes in Florida are bacterial, fungal and viral diseases. Bacterial and fungal diseases are typically associated with wet climates as can be expected in neutral and El Niño years. Some cultivars are more tolerant than others to diseases such as bacterial spot, for example FL47 and FL91 types. The whitefly is a vector of tomato yellow leaf curl virus (TYLCV), and causes irregular ripening This condition causes fruit to ripen on the outside but internal tissue does not ripen properly. Currently, some varieties exist that are tolerant to TYLCV. Many of these varieties were developed in arid climates and do not perform as well under certain Florida environmental conditions. Florida breeding programs are also working on new tolerant or resistant cultivars. La Niña Fall and Winter are typically less rainy than normal.
White flies are a desert insect and like dry weather. Whitefly and many other insects are typically more numerous under dry conditions. Higher temperatures also have an impact on reproduction rates and transmission, with more reproductive cycles and thus increased chance for transmission during dry conditions. Due to the magnitude of white fly outbreak in Florida in recent years, researchers are encouraging growers to maintain a crop or host free period of at least six weeks in summer.

In the Ruskin area there is more virus outbreak in the fall. Early plantings should be virus tolerant cultivars. Even these varieties allow viruses to multiply and can serve as a symptomless host, thus whitefly controls should still be used. In Immokalee, the same is true for spring when populations may explode as early as February. The last plantings in spring should be with virus (white fly)-tolerant varieties. Whole crops have been lost due to this problem in past years.

\section{Heat Tolerance}

An important constraint in the past was getting fruit to set when night temperatures remain above $65^{\circ} \mathrm{F}$. Hot set varieties are available. Fall of 2002 was hot with abundant rain. The night temperatures were in the $70 \mathrm{~s}$, which created a problem for fruit set. The choice in that situation is to go with hot set varieties. However, some heat tolerant varieties present problems. Small very determinate plants are more susceptible to bacteria. That is why it is often necessary to get away from hot sets toward more vigorous plants. Hot sets have a wider range of adaptability but the plants are not as vigorous. The plant is fighting between vegetative and reproductive growth. Rough shoulders and blossom scars may appear in cold weather. In a predicted hot season, plantings should be concentrated on early fruit sets, such as in La Niña Springs.

\section{Yields}

Few major differences in yield exist among major varieties used in Florida. Differences could be attributed to growing or cultural conditions (fertilization, water, pruning, etc.). Differences might also include how a variety handles weather and how 
concentrated the fruit set is. Growers might select a variety that has a greater fruit set for the first pick if there were to be a predicted change in climate.

\section{Fruit Quality}

One factor that might be influenced by climate is flavor. Climate could be important for superior quality tomato. Rain would be a problem if harvesting ripe tomatoes. More tomatoes are being harvested at breaker color. A variety harvested later could make more profit and offset yield reduction but also requires different handling and marketing than mature green tomatoes. Predicted climate may influence these decisions.

\section{Cultivation Practices}

\section{Land Preparation}

Climate-based land preparation management changes are a difficult option for producers. If producers were expecting a wetter fall they might dig deeper ditches in some production regions. This is a common practice in some areas and is only marginally more expensive. In other areas, ditches are often dug to a depth correlated to bed height and digging deeper ditches might make water management more difficult, especially for seepage-irrigated fields. Applications of herbicide to ditches would be too extreme a measure because erosion problems might outweigh the benefits of improved drainage. Sediment and pesticide runoff can be major problems (and will become even more scrutinized under TMDL guidelines) and must be taken into consideration. Bed height is standard, with equipment being fixed and expensive. If bed height were adjustable, higher beds might be an option for wet years, although this would also impact water management. Care must be taken to avoid going from very wet to very dry. In Homestead, beds would have to be higher and narrower because there is a finite amount of soil.

\section{Fertilization}

Like land preparation, fertilization practices are only slightly changeable based on climate forecasts in tomato. Common practice consists of using plastic covered beds. Some of the fertilizer is broadcast within the bed, typically all of the $\mathrm{P}$ and micronutrients and some $\mathrm{N}$ and $\mathrm{K}$. Two bands of hot mix are added, which contain mostly nitrogen and potassium. Additionally, micronutrients can be added through injection and foliar applications. $\mathrm{N}$ and $\mathrm{K}$ can also be injected. Fertilizer is not expensive, and is often used at higher than IFAS recommendations. This is a form of risk avoidance: If they knew ahead of time of an upcoming wetter winter, growers might increase the percentage of slow release fertilizer in their fertilizer program. Approximately $70 \%$ of producers use drip irrigation and 'spoon-feed' fertilizer to the plants, thus the ability to make adjustments in fertilizer applications is already in place. Growers utilizing seep irrigation might actually increase fertilizer amounts if a wet season were predicted, but this would not be recommended, due to potential leaching consequences. In very rainy years (El Niño), leaching can be high. Growers might add more fertilizer or change to slow release.

\section{Irrigation}

Irrigation in tomato is a practice that can be altered little with regard to ENSO phases. Common practice consists of three types of irrigation: seep, drip, and fully enclosed subsurface (FES). Once an irrigation decision has been made for a farm and a system installed, it cannot be easily changed. Most producers are moving to drip because of water regulations and restrictions. In some tomato producing areas, the spodic layer or 'hard pan' allows producers to perch the water table. It is this fact upon which the standard seep system and the FES system are based. Changes in irrigation infrastructure require engineering work, which is expensive and cannot be done on short-term notice. The type of irrigation system to be installed is generally decided by the packinghouse owner or manager because this is a high cost input.

Special cases include Homestead where the highest place in the county is $18^{\prime}$ and the lowest are 4-6'. Canals were built to provide drainage -not irrigation. Getting rid of excess water is the main problem. Irrigation to mitigate freezes uses 1/4-inch per hour and does not work in strong wind. 


\section{Part Three: Risk and Economic Implications of Seasonal Climate Variability Forecasts on Tomato}

\section{ENSO, Crop Yields and Profits}

ENSO influences Southeastern weather, particularly our winter precipitation, which in turn affects yields for many crops. But how does that translate into profits or losses? To answer that question, we must consider how ENSO contributes to fluctuations in farm incomes. Because ENSO is but one of many sources of farm risk, use of climate information should be coordinated with other agricultural risk management tools for best results. Figure 2 shows how ENSO phases historically influence average tomato yields.

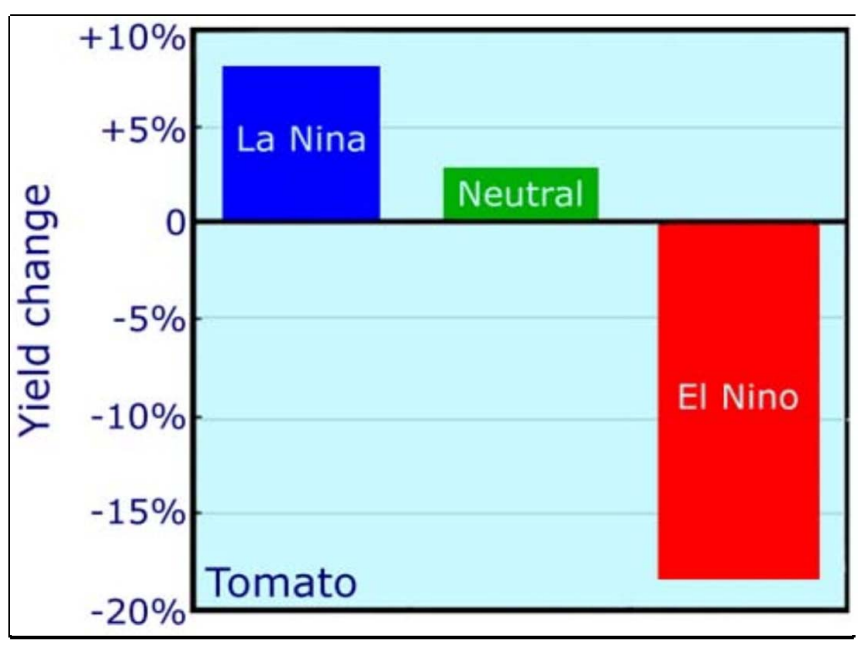

Figure 2. Influence of ENSO Phases on Florida Tomato Yields

\section{Managing Risk}

Farmer's face shifting weather, yields, prices, government policies and growing international competition that may reduce their financial returns and well-being. Risk management can reduce such economic swings and does so by reducing risk within the farm (e.g., diversification), transferring risk outside the farm (e.g., production contracting), or building risk-bearing capacity (e.g., maintaining cash reserves).
Producers often cite uncertain commodity prices and yield declines as risk factors of greatest concern. Of course shifting prices and yields usually do influence one another, but trade flows from other production regions usually tend to keep this relationship weak. In major production areas such as South Florida, price-yield relationship is both strong and offsetting, providing growers with a natural hedge that stabilizes revenues.

\section{South Florida is a Major Producer of Winter Tomatoes}

South Florida is a major production region for winter-grown fresh market tomatoes. Florida has $40 \%$ of the US fresh tomato market, and provides essentially all of the US winter production of tomatoes (Florida Department of Agriculture and Consumer Services, 2000). High yields tend to depress tomato prices, since then consumers need encouragement in the form of lower prices.

Conversely, low tomato yields tend to raise prices, as consumers must pay more to obtain the more scarce fruit. In spite of this economic trend, many tomato growers report that super market prices for consumers do not come down much with high yields. When yields are low, prices might be slightly higher for consumers, but producers see little of this mark-up.

Research found the average yield reduction in $\mathrm{El}$ Niño years for winter tomato was $28 \%$ of the long-term average; however, winter tomato crop value averaged just $22 \%$ lower, in part because of offsetting price effects.

\section{More Imports May Mean More Risk}

Increasing imports since the mid-1990s, and especially since passage of the North American Free Trade Agreement, have reduced South Florida's share of the winter tomato market. USDA reports that imports accounted for 32 percent of fresh tomato consumption in 1999, up from 19 percent in 1994.

Increased imports have probably also reduced the tendency of price and yield changes to offset one another. If so, South Florida's tomato growers may wish to consider alternative ways to stabilize revenues, such as crop insurance or marketing contracts. For more details on available risk 
management options, see the Internet Web site for the USDA's Risk Management Agency at <http://www.rma.usda.gov/policies/>. USDA/RMA cautions growers to carefully consider how risk management tools such as climate information and crop insurance policy will work together as part of a comprehensive risk management strategy to achieve the best possible outcome.

\section{ENSO Effects on Prices}

\section{Climate Forecasts and Producer Prices}

Climate forecasts, like other technical innovations, are not an unambiguous boon to producers and should be used with care. Fresh tomato growers have expressed concern about the possibility of a negative impact of climate prediction, because of the commanding influence of a few decision makers. Some growers have noted that attempts to increase production by using climate forecasts could worsen existing over-capacity problems and lead to yet lower prices. With a few dominant decision makers, forecast value will depend in part upon whether or not decision-makers can or are willing to coordinate their production plans. At present the individual grower's only option is to maximize yield and have product available during the entire market window.

\section{Market Conditions}

If climate forecast usage does lead to falling producer prices, market conditions no doubt will play a critical role in determining how much. The value of using forecasts, in a given year or over the longer term, will largely depend on how much fruit is being offered compared to how much consumers want to buy.

A basic consideration is how much market prices must fall if over-production does occur. The price elasticity of demand measures, in percentage terms, the responsiveness of consumers to changing prices. So, for example, a price elasticity of demand of -0.45 implies that if producers try to sell $45 \%$ more tomatoes in the winter season, the price would have to fall by $100 \%$; if prices were to double, consumers would buy $45 \%$ fewer tomatoes. In our research (Messina et al. 2003), we have estimated a winter season demand elasticity of -0.45 .

\section{Climatic Effects on Production Elsewhere}

Growers often say they can make a profit only if someone else has a bad year. One possible use for climate forecasts would be if they could foretell poor harvests in other important production regions. For example, growers in Homestead and Immokalee have shown as much interest in how ENSO might affect Mexican growing conditions as it may their own. Unfortunately, climate forecasts do not offer much predictability for the Mexican states that are of greatest interest to winter growers, Sinaloa and Baja California Norte, where typically $75-90 \%$ of Mexican fresh tomato exports are grown. An ENSO signal exists for these Mexican states but is too noisy to serve as a helpful guide for agricultural decision making (Magaña, 2003). Climatic fluctuations do affect tomato yields in Sinaloa and Baja, but not in a way we can anticipate since interactions between ENSO and another source of variability, the Pacific North American pattern, are not well understood for this region. The lack of predictability is similar elsewhere, for different reasons, whether for domestic (e.g., CA, PA, OH, VA, NJ, TN, SC or NY) or foreign (e.g., Canada or Netherlands) production regions.

\section{A Note of Caution}

Climate forecasts are an emerging technical innovation that can bring economic relief to Florida's tomato growers, in the form of lower production costs. If, as seems likely, tomato growers' responses to ENSO forecasts will affect agricultural markets, growers should consider those market changes when deciding whether to use forecasts. The prospect of decreasing forecast value with increasing usage suggests a need for a coordinated effort among decision-makers, perhaps with extension assistance, to develop climate forecast applications that tend to reduce costs, rather than increase production.

\section{Insurance}

Climate Information as Part of a Risk Management Strategy for Tomato Growers -- Climate information is but one risk management tool available to tomato growers, who are all too familiar with risk. Risk management in general seeks the best 
combination of risk and return available, given the person's capacity to withstand the range of possible outcomes (Harwood et al. 1999). Fortunately, an increasing number of risk management tools are available to help tomato producers.

\section{Crop Insurance for Fresh Tomato Growers}

Government supported farm risk management tools have proliferated in recent years, largely due to the Agricultural Risk Protection Act of 2000. Over 200 million acres are now covered by crop insurance, and government insurance subsidies are expected to average over $\$ 2$ billion annually during the next few years (USDA/ERS 2003). USDA's Risk Management Agency (RMA) helps administer two different types of crop insurance for Florida's fresh tomato growers.

\section{Actual Production History (APH)}

Insures producers against yield losses due to natural causes such as drought, excessive moisture, hail, wind, frost, insects and disease. The farmer selects the amount of average yield to insure, from 50 to 75 percent (in some areas to 85 percent). The farmer also selects the percent of the predicted price to insure; between 55 and 100 percent of the crop price established annually by RMA. If the harvest is less than the yield insured, the farmer is paid an indemnity based on the difference. Indemnities are calculated by multiplying this difference by the insured percentage of the established price selected when crop insurance was purchased.

\section{Dollar Plan (DOL)}

Insures against declining value due to damage that causes a yield shortfall. Insured amount is based on the cost of growing a crop in a specific area. A loss occurs when the annual crop value is less than the insured amount.Some $178 \mathrm{APH}$ and DOL policies have been sold to Florida tomato growers in 2003 that protect more than 27,000 acres, or about $60 \%$ of the 2002 planted acreage of 45,000. For more details on available crop insurance options, see the USDA/RMA Internet web site at $<$ http://www.rma.usda.gov/policies/>. USDA/RMA cautions growers to carefully consider how a crop insurance policy will work in conjunction with their other risk management tools to achieve the best possible outcome. The dollar plan is most widely used in South Florida.

\section{Risk Management Tailored to the Individual Grower}

Managing farm risk is complicated for a host of reasons. Growers do not manage weather risk in isolation but rather as part of more comprehensive strategies that also consider risks posed by price fluctuations and policy changes. Also, farmers differ in their attitudes toward risk and in their abilities to respond to risky situations, so risk management must be tailored to the individual producer. Crop insurance agents and other agri-business specialists listed in the USDA/RMA agent locator <http://www3.rma.usda.gov/tools/agents/> can assist farmers in developing a good management plan. Risk management tools, such as climate information and crop insurance, often work best when they are used together.

\section{Information Sources for the Southeastern United States on EI Niño, La Niña and Neutral Climates}

Information about the current El Niño/La Niña status and the implications for Florida climate are provided by The Southeast Climate Consortium and can be found on the Web at <www.agclimate.org>, and at a related weather site:

$<$ http://fawn.ifas.ufl.edu>.

\section{Additional Resources}

USDA publishes reports on vegetable and melon production, available on the Internet at: <http://www.ers.usda.gov/publications/vgs/dec01/ vgs288.pdf $>$.

\section{References}

Florida Department of Agriculture and Consumer Services, 2000.

<http://www.doacs.state.fl.us/fruits/>.

Fraisse.C., Uryasev, O., and Jones, J.W. 2004. Crop Yield Risk Assessment Tool.

<www.AgClimate.org> 
Harwood, J., Heifner, R., Coble, K., Perry, J, and Somwaru, A. 1999. Managing Risks in Farming. USDA/ERS AER 774.

Lucier, Gary, and Plummer, Charles. 2001. Vegetables and Melons Outlook. USDA Publication VGS-288. US Department of Agriculture. Available on the Web at:

$<$ http://www.ers.usda.gov/publications/vgs/dec01/ vgs288.pdf>.

Magaña, V. 2003. Fundamentos de la predicción climática: Modelación numérica. CCA, UNAM. . Presentado en : Primer taller en Materia de Predicción Climática en Centroamérica y México y V Foro sobre la Predicción Climática en México

Messina, C. D., Letson, D., Jones, J.W. 2003. Tailoring Management of Tomato Production to ENSO Phase at Different Scales in Florida and Puerto Rico, submitted, in review.

Messina, C.D., Jones, J.W., Hansen, J.W. 2001. Understanding ENSO Effects on Tomato Yields in Florida: A Modeling Approach. In: Proceedings of the 2nd International Symposium Modeling Cropping Systems, Florence, Italy. Pp. 155-156.

Miller,G.L., Park-Brown, S., Stiles, C., Dukes, M., Royce, F., Jones, J.W., Zazueta, F.S., and Zierden, D. 2001. Climate-based Management of Lawns. IFAS Publication AE 319, Agricultural and Biological Engineering Department, Florida Cooperative Extension Service, Institute of Food and Agricultural Sciences, University of Florida. This publication available on the EDIS Web Site at <http://edis.ifas.ufl.edu>.

O'Brien, J.J., Zierden, D.F., Legler, D., Hansen, J.W., Jones, J.W., Smajstrla, A.G., Podestá, G.P., and Letson,D. 1999. El Niño, La Niña and Florida's Climate: Effects on Agriculture and Forestry. The Florida Consortium Staff Paper.(Florida State Univ., Univ. of Florida and Univ. of Miami, Gainesville, Florida, USA.)

Simonne, E., Hochmuth, G., 2003. Frost and Freeze Protection for Vegetable Crops Grown in Florida in the BMP Era. IFAS Publication HS911.
Horticultural Sciences Department, Florida

Cooperative Extension Service, Institute of Food and Agricultural Sciences, University of Florida. This publication is available on the EDIS Web site at: $<$ http://edis.ifas.ufl.edu/BODY_HS168>. 
Table 1. How ENSO Phases Influence Conditions in Southern Florida. Source: Miller et al. 2001.

\begin{tabular}{|c|c|c|c|c|}
\hline \multirow[t]{2}{*}{ Phase } & \multicolumn{4}{|l|}{ Seasons } \\
\hline & Oct-Dec & Jan-Mar & Apr-Jun & Jul-Sep \\
\hline El Niño & $\begin{array}{l}\text { Wet } \\
\text { Cool }\end{array}$ & $\begin{array}{l}\text { Strong wet } \\
\text { Strong cool }\end{array}$ & Weak dry & Normal \\
\hline La Niña & $\begin{array}{l}\text { Dry } \\
\text { Weak warm }\end{array}$ & $\begin{array}{l}\text { Strong dry } \\
\text { Strong warm }\end{array}$ & Weak wet & $\begin{array}{l}\text { Normal } \\
\text { Weak cool }\end{array}$ \\
\hline Neutral & Normal & Normal & Normal & Normal \\
\hline
\end{tabular}

Table 2. Tomato Variety Options for Southern Florida in different ENSO Phases.

\begin{tabular}{||l|l|l|l||}
\hline \hline \multirow{2}{*}{ Phase } & \multicolumn{2}{|l|}{ Season } & \multicolumn{2}{l||}{} \\
\cline { 2 - 3 } & Oct-Dec & Jan-Mar & Jul-Sep \\
\hline El Niño & $\begin{array}{l}\text { Use varieties tolerant to } \\
\text { Fusarium races 1, 2, } 3 ; \\
\text { and soil-borne fungal } \\
\text { problems }\end{array}$ & $\begin{array}{l}\text { Use varieties tolerant to } \\
\text { Fusarium races 1,2 \& 3; } \\
\text { and soil-borne fungal } \\
\text { problems }\end{array}$ & $\begin{array}{l}\text { Use varieties tolerant to } \\
\text { disease transmitted by } \\
\text { thrips and white fly (TYLCV) }\end{array}$ \\
\hline La Niña & $\begin{array}{l}\text { Use varieties tolerant to } \\
\text { diseases transmitted by } \\
\text { thrips and white fly } \\
\text { (TYLCV). Hot sets for early } \\
\text { plantings. }\end{array}$ & $\begin{array}{l}\text { Use varieties tolerant to } \\
\text { diseases transmitted by } \\
\text { thrips and white fly } \\
\text { (TYCLV). Hot sets for most } \\
\text { plantings, especially later } \\
\text { ones. Varieties that } \\
\text { concentrate fruit set on first } \\
\text { pick. Fungal disease } \\
\text { resistance is not as } \\
\text { important a criterion as } \\
\text { usual. }\end{array}$ & \\
& & Normal & \\
& & Normal & \\
\hline Neutral & Normal & Normal \\
\hline \hline
\end{tabular}

